\title{
OPTIMASI METODE EKSTRAKSI BERBANTU MIKROWAVE DENGAN PELARUT HIJAU (ASAM SITRAT-GLUKOSA) TERHADAP KADAR POLIFENOL TOTAL DARI DAUN KADAMBA (Mitragyna speciosa Korth. Havil) MENGGUNAKAN RESPONSE SURFACE METHODOLOGY
}

\author{
Islamudin Ahmad ${ }^{1,3}$, Wisnu Cahyo Prabowo², Yuspian Nur ${ }^{3}$, Mirhansyah Ardana², Bakti Puji \\ Rahayu $^{1}$, Herman ${ }^{1}$ \\ ${ }^{1}$ Program Studi Sarjana (S1) Farmasi, Fakultas Farmasi, Universitas Mulawarman, Samarinda, \\ Kalimantan Timur, Indonesia \\ ${ }^{2}$ Program Studi Diploma III (D3) Farmasi, Fakultas Farmasi, Universitas, Mulawarman, Samarinda, \\ Kalimantan Timur, Indonesia \\ ${ }^{3}$ Laboratorium Riset dan Pengembangan Kefarmasian "FARMAKA TROPIS", Fakultas Farmasi, \\ Universitas, Mulawarman, Samarinda, Kalimantan Timur, Indonesia
}

\section{Kata Kunci}

Kadamba (Mitragyna speciosa Korth Havil), Kadar Polifenol Total, Natural Deep Eutectic Solvent, Response Surface Methodology

\begin{abstract}
ABSTRAK
Kadamba (Mitragyna speciosa Korth Havil) merupakan salah satu tumbuhan endemik di Asia Tenggara, di Indonesia, tumbuhan ini banyak di jumpai di pulau Kalimantan. Tumbuhan ini dipercaya oleh masyarakat dapat mengobati berbagai macam penyakit. Namun, karena kandungan alkaloidnya, tumbuhan ini dilarang digunakan sebagai bahan baku obat herbal oleh Badan Pengawas Obat dan Makanan. Oleh karena itu, perlu dilakukan pengembangan metode ekstraksi untuk menarik senyawa metabolit sekunder target dan meminimalkan senyawa yang tidak diinginkan yaitu dengan menggunakan metode ekstraksi berbantu mikrowave dengan pelarut hijau (Natural Deep Eutectic Solvent) yang dioptimasi menggunakan response surface methodology (RSM). Simplisia kering daun Kadamba diekstraksi menggunakan metode ekstraksi berbantu mikrowave dengan pelarut hijau (asam sitrat-glukosa) dengan berbagai kondisi ekstraksi dengan empat faktor dan tiga level (Box Behnken Design) yang dioptimasi menggunakan RSM dengan aplikasi perangkat lunak Design Expert versi 12 berlisensi. Penetapan kadar polifenol total dilakukan menggunakan reagen Folin-Ciocalteau dan diukur absorbansinya pada spektrofotometer UV-Vis pada panjang gelombang $770 \mathrm{~nm}$, serta asam gallat sebagai standar. Berdasarkan hasil penelitian, diperoleh kondisi optimum pada perbandingan rasio pelarut NADES (asam sitrat : glukosa) 5:1 g/g, rasio pelarut-sampel sebesar 1:20 g/mL, waktu ekstraksi selama 20 menit dan kekuatan gelombang mikro sebesar 30\% dengan kadar polifenol total prediksi sebesar $314,924 \pm 35,95 \mathrm{mg} \mathrm{GAE} / \mathrm{g}$ sampel, sedangkan dari hasil proses verifikasi (scale-up confirmation) yaitu dengan meningkatkan jumlah sampel yang digunakan sebanyak sepuluh kali lipat dengan Kadar polifenol total diperoleh sebesar 427,12 $\pm 35,95 \mathrm{mg} \mathrm{GAE} / \mathrm{g}$. Penelitian ini merupakan langkah awal dalam pengembangan metode ekstraksi untuk memperoleh senyawa target secara cepat, mudah, efisien, dan ramah lingkungan.
\end{abstract}

\section{PENDAHULUAN}

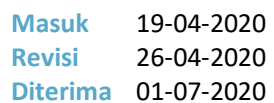

Diterima 01-07-2020

DOI: $10.20956 / m f f . v 24 i 1.9456$

Korespondensi

Islamudin Ahmad

islamudinahmad@farmasi.unmul.ac.id

Copyright

(C) 2020 Majalah Farmasi

Farmakologi Fakultas Farmasi Makassar

Diterbitkan tanggal

01 Juli 2020

Dapat Diakses Daring Pada: http://journal.unhas.ac.id/index.php/mff
Kadamba (Mitragyna speciosa Korth Havil) merupakan salah satu tumbuhan yang banyak ditemukan di Asia Tenggara terutama dari Indonesia, Malaysia, dan Thailand (1). Di Indonesia, tumbuhan ini banyak ditemukan di Pulau Kalimantan, terutama kalimantan Timur. Bagian yang paling banyak digunakan adalah bagian daun. Masyarakat sekitar mengenal daun kadamba dengan sebutan daun purik atau di Asia dan Dunia lebih dikenal dengan nama Kratom. Secara umum, tumbuhan ini dikonsumsi dengan cara di isap seperti rokok, di kunyah, dan di seduh (2). Secara tradisional, masyarakat menggunakana daun tumbuhan ini untuk mengatasi nyeri otot, penyakit gula (diabates), diare, batuk, penambah energi, mengatasi depresi, dan stimulan seksual (2)(3). Terdapat 40 jenis alkaloid yang terkandung didalam tumbuhan Kadamba, diantaranya spesioginin, painantein, spesiosiliatin, 7hidroksiitraginin, mitraginin, jenis lain seperti polifenol, terpenoid, flavanoid, glikosida(4). Namun, berdasarkan Peraturan Kepala Badan Pengawas Obat dan Makanan Nomor HK.00.05.23.3544 menyatakan bahwa tumbuhan ini dilarang digunakan sebagai bahan baku obat tradisional karena mengandung alkaloid mitraginin yang memiliki efek narkotik.

Oleh karena itu, sangat penting untuk dilakukan pengembangan metode ekstraksi dalam rangka pemanfaatan daun kadamba yang kaya akan khasiat ini. Pengembangan metode ekstraksi diharapkan secara selektif dapat menarik senyawa-senyawa metabolit sekunder target secara optimal. Salah satu metode yang dikembangkan oleh penulis adalah pengembangan metode ekstraksi berbasis green chemistry atau kimia hijau dengan penggunaan pelarut hijau Natural Deep Eutectic Solvent (NADES). Dilihat dari segi sifat fisikokimianya, 
NADES memiliki beberapa keuntungan yang tidak dimiliki oleh pelarut organik konvensional diantaranya memiliki sifat stabil pada suhu tinggi, tidak mudah menguap, tidak toksik, ramah lingkungan (5), dan food grade (6). Beberapa penelitian telah melaporkan tentang penggunaan NADES sebagai pelarut alternatif seperti ekstraksi kafein dan polifenol dari biji kopi (6), ekstraksi kuersetin dari bawang merah (7), ekstraksi oxyresveratrol dari Morus alba (8), ekstraksi $\alpha$-mangostin dari kulit buah manggis (9), dan lainlain. Namun, sejauh pengetahuan kami, penggunaan NADES sebagai pelarut alternatif untuk mengekstraksi senyawa metabolit sekunder target dari daun Kadamba belum pernah dilaporkan.

Pada penelitian ini, Penggunaan NADES sebagai pelarut hijau yang dikombinasikan dengan metode ekstraksi nonkonvensional berbantu mikrowave atau dikenal dengan istilah Microwave-Assisted Extraction (MAE), diharapkan dapat diperoleh kondisi ekstraksi yang efisien, mudah, cepat, dan ramah lingkungan. Pada metode MAE, memiliki beberapa keunggulan dimana proses ekstraksi berlangsung secara singkat, mengurangi gradien panas, senyawa target yang dihasilkan tinggi, dan meminimalkan penggunaan pelarut (10). Optimasi metode ekstraksi dilakukan dengan menggunakan Response Surface Methdodology (RSM). RSM merupakan suatu pemodelan dalam pendekatan secara empiris untuk mengetahui hubungan dan permasalahan dari beberapa variabel dengan mencari nilai optimum dari suatu respon (variabel terikat). RSM menggunakan prosedur matematika dan statistika untuk pemodelan dan analisis hasil eksperimen untuk menentukan paramater signifikan yang mempengaruhi pengoptimalan dari respon yang dihasilkan (11).

Penelitian ini bertujuan untuk mengetahui kondisi optimum dari metode ekstraksi berbantu mikrowave dengan pelarut hijau NADES (asam sitrat-glukosa) terhadap kadar polifenol total dari daun Kadamba (Mitragyna speciosa Korth. Havil) menggunakan Response Surface Methodology (RSM)

\section{METODE PENELITIAN}

\section{Bahan dan Alat}

Bahan-bahan yang digunakan pada penelitian ini meliputi: Daun Kadamba segar diperoleh dari Melak, Kabupaten Kutai Barat, kemudian diidentifikasi di Laboratorium Dendrologi Fakultas Kehutanan Universitas Mulawarman, kemudian diolah menjadi simplisia kering di Laboratorium Riset dan Pengembangan Kefarmasian "FARMAKA TROPIS" Fakultas Farmasi Universitas Mulawarman, Samarinda. Asam sitrat dan glukosa diperoleh dari CV. Chlorogreen Bandung, reagen Folin-Ciocalteau, asam gallat, dan natrium carbonat diperoleh dari Sigma Aldrich USA (melalui PT. Elo Karsa Utama), Sedangkan peralatan yang digunakan meliputi: sebuah komputer laptop yang telah terinstall perangkat lunak Design Expert versi 12 berlisensi, Mikrowave domestik 900 Watt (Modena, USA) yang telah dimodifikasi, spektrofotmeter UV-Vis (Shimadzu, Jepang), mikropipet, dan peralatan gelas lainnya.

Cara Kerja

Preparasi NADES

Pada penelitian ini, NADES yang digunakan terdiri dari kombinasi antara asam sitrat dengan glukosa yang dibuat dalam tiga jenis level kombinasi konsentrasi yang bertingkat yaitu 4:1, 5:1, dan 6:1 g/g (asam sitrat:glukosa) dan mengacu pada beberapa penelitian sebelumnya $(6,12,13,14,15)$ dengan beberapa modifikasi untuk menyesuaikan kestabilan NADES. Pertama-tama, asam sitrat dan glukosa ditimbang berdasarkan masing-masing konsentrasi rasio yang dibuat.
Kedua bahan tersebut dilebur pada suhu tertentu menggunakan magnetik strirrer. Setelah melebur kemudian secara perlahan ditambahkan aquades sebanyak 50\%, kemudian dihomogenkan. Selanjutnya, larutan tersebut didinginkan pada suhu kamar, pelarut tersebut disimpan pada botol yang tertutup rapat hingga digunakan.

\section{Proses Ekstraksi}

Proses ekstraksi polifenol total dari daun kadamba dilakukan menggunakan metode ekstraksi nonkonvensional berbantu mikrowave yang dikombinasikan dengan penggunaan pelarut hijau NADES yang tersusun dari kombinasi asam sitrat dan glukosa menggunakan berbagai kondisi ekstraksi berdasarkan beberapa literatur $(14,16,17,18,19,20)$. Ringkasnya, sebanyak 3 g serbuk simplisia daun kadamba kering diekstraksi menggunakan metode ekstraksi berbantu mikrowave dan pelarut hijau NADES (asam sitrat-glukosa) dengan berbagai kondisi ekstraksi yang berbeda yang meliputi rasio NADES, rasio pelarut-sampel, waktu ekstraksi, dan kekuatan mikrowave sebagai mana yang terlihat pada Tabel 1. Kemudian, setelah selesai ekstraksi, larutan ekstrak dan residu dipisahkan menggunakan corong Buchner. Larutan ekstrak yang diperoleh disimpan pada suhu kamar hingga dilakukan analisis.

\begin{tabular}{|c|c|c|c|c|c|}
\hline \multirow{2}{*}{ Faktor } & \multirow{2}{*}{ Unit } & \multirow{2}{*}{ Simbol } & \multicolumn{3}{|c|}{ Level } \\
\hline & & & -1 & 0 & 1 \\
\hline Rasio NADES & $\mathrm{g} / \mathrm{g}$ & A & 4 & 5 & 6 \\
\hline Rasio Pelarut-Sampel & $\mathrm{ml} / \mathrm{g}$ & B & 10 & 15 & 20 \\
\hline Waktu Ekstraksi & Menit & C & 10 & 15 & 20 \\
\hline Kekuatan Mikrowave & $\%$ watt & D & 10 & 30 & 50 \\
\hline
\end{tabular}

\section{Penetapan Kadar Polifenol Total}

Penetapan kadar polifenol total dilakukan menggunakan spektrofotometer UV-Vis pada panjang gelombang $770 \mathrm{~nm}$ dan reagen Folin-Ciocalteau yang diadposi dari berbagai pustaka $(21,22,23,24)$, dengan beberapa modifikasi kondisi untuk menyesuaikan absorbansi yang diinginkan. Diambil 1 mL larutan sampel dan atau larutan standar kemudian dimasukkan kedalam tabung reaksi, ditambahkan $0,5 \mathrm{~mL}$ reagen Folin-Ciocalteau. Kemudian didiamkan selama 5 menit lalu tambahkan $2 \mathrm{~mL} \mathrm{Na}_{2} \mathrm{CO}_{3}$, kemudian diinkubasi selama 30 menit. Pengukuran dilakukan menggunakan Spektrofotometer Uv-Vis. Larutan standar asam gallat dengan berbagai konsentrasi dari 12,5 ppm hingga 200 ppm untuk memperoleh persamaan regresi linier yaitu $\mathrm{Y}=$ 0,0022X-0,00095, dengan nilai R2 sebesar 0,9977, persamaan ini digunakan untuk menghitung kadar polifenol total dari ekstrak daun kadamba.

Prosedur Optimalisasi Menggunakan Response Surface Methdology (RSM)

Optimalisasi kondisi ekstraksi dari metode ekstraksi nonkovensional berbantu mikrowave dengan pelarut hijau NADES (asam sitrat-glukosa) dilakukan menggunakan RSM yang dioperasikan dengan perangkat lunak Design Expert versi 12 (DE12) berlisensi. Desain eksperimen dirancang dengan pendekatan Box Behnken Design (BBD) yang terdiri dari empat faktor dengan tiga level yang memerlukan 29 eksperimen (dengan variabel parameter yang berbeda dan dilakukan secara triplo) seperti yang disajikan pada Tabel 1. Variabel bebas terdiri dari rasio $\operatorname{NADES}(4,5$, dan $6 \mathrm{~g} / \mathrm{g}$ ), rasio pelarut-sampel $(10: 1,15: 1$, dan $20: 1 \mathrm{ml} / \mathrm{g})$, waktu ekstraksi $(10,15$, dan 20 menit), dan kekuatan mikrowave $(10,30$, dan $50 \%$ watt), sedangkan variabel terikat adalah respon dalam bentuk kadar polifenol total (mg GAE/g sampel). Persamaan regresi dari model terbaik dianalisis berdasarkan data hasil eksperimen dari proses ekstraksi 
dengan kondisi yang bervariasi terhadap kadar polifenol total dengan regresi multilinier kuadratik model $(17,20,25,26,27)$.

\section{HASIL DAN PEMBAHASAN}

Kadamba merupakan tanaman yang memiliki manfaat alternatif pada penyakit hipertensi, diabetes, rasa sakit, batuk, diare, dan sebagai pengganti dalam mengatasi kecanduan morfin (28) selain itu juga kadamba biasanya digunakan untuk mengurangi nafsu makan, obat demam, antiinflamasi, antioksidan, dan antibakteri (29,30,31). Didalam daun kadamba terdapat 40 jenis alkaloid di antaranya adalah mitraginin, 7-hidroksimitraginin, painantein, spesioginin, spesiosiliatin, beberapa jenis flavonoid, terpenoid, saponin, dan beberapa jenis glikosida $(2,4)$.

Pada umumnya, ekstraksi senyawa fitokimia masih banyak bermasalah dan membingungkan dalam proses penelitian. Berbagai jenis metode ekstraksi yang digunakan dapat mempengaruhi aktivitas biologis dari senyawa fitokimia dalam penemuan obat dari bahan alam. Pemilihan metode bergantung pada jenis bahan dan sifat senyawa yang akan diisolasi (32). Pemilihan metode sangatlah penting terutama dalam menarik senyawa dan menghasilkan senyawa yang lebih spesifik sehingga akan meningkatkan ketersediaan metabolit sekunder yang diperlukan.

Pada penelitian ini, pengembangan metode ekstraksi dengan pendekatan prinsip green chemistry atau kimia hijau yang bertujuan untuk meningkatkan kadar senyawa metabolit sekunder target atau spesifik dari sampel tumbuhan atau bahan alam lain telah dilakukan dalam satu dekade belakangan. Penggunaan pelarut hijau (dalam penelitian ini menggunakan asam sitrat: glukosa) memiliki keuntungan seperti tidak mudah terbakar, tidak toksik, ramah lingkungan, dan edible (karena jenis pelarut ini masuk dalam kategori food grade) $(33,34)$. Selain itu, peningkatan kadar senyawa metabolit sekunder target juga dipengaruhi oleh kondisi ekstraksi dari metode ekstraksi berbantu mikrowave yang digunakan (10). Beberapa faktor atau parameter kondisi ekstraksi yang digunakan pada penelitian ini meliputi rasio NADES, rasio pelarut-sampel, waktu ekstraksi, dan kekuatan mikrowave. Ekstraksi senyawa target polifenol dari daun kadamba dilakukan menggunakan pelarut hijau (NADES) dengan komponen antara rasio asam sitrat dan glukosa yang dikombinasikan dengan metode ekstraksi nonkonvensional yaitu ekstraksi berbantu mikrowave.

Pemilihan metode ekstraksi didasarkan pada berbagai pertimbangan seperti efisiensi waktu, efisiensi biaya, jumlah pelarut yang digunakan, dan lain sebagainya. Pada penelitian ini, proses ekstraksi dilakukan dengan empat faktor dan tiga level menggunakan BBD yang terdiri dari 29 eksperimen dengan berbagai kondisi ekstraksi terhadap kadar polifenol total, seperti yang ditunjukkan pada Tabel 1. Pada tabel tersebut, asam sitrat-glukosa dengan berbagai variasi konsentrasi yang kemudian dilebur pada kondisi tertentu dan penambahan air. Dimana asam sitrat berperan sebagai hydrogen bond acceptor (HBA) dan glukosa berperan sebagai hydrogen bond donor (HBA) $(6,26,35,36,37)$. Metode RSM digunakan untuk menganalisis pengaruh atau interaksi antara faktor-faktor yang digunakan seperti yang disajikan pada Tabel 1. Analisis RSM dilakukan dengan menggunakan perangkat lunak DE12 untuk menganalisis dan memperoleh kondisi optimum pada proses ekstraksi kadar polifenol dari daun Kadamba. Pada proses analisis digunakan pendekatan BBD yang terdiri dari empat faktor dengan tiga level yang meliputi rasio NADES (rasio antara asam sitrat dengan glukosa yaitu 4:1, 5:1, 6:1 g/g), rasio pelarut-sampel (10:1, 15:1, dan 20:1 ml/g), waktu ekstraksi $(10,15$, dan 20 menit), dan kekuatan mikrowave $(10,30$, dan $50 \%$ watt) terhadap kadar polifenol. Proses ekstraksi pada kondisi eksperimental berbeda dan kadar polifenol total yang ditunjukkan pada Tabel 2.

\begin{tabular}{|c|c|c|c|c|c|c|c|}
\hline Std & Run & $\begin{array}{c}\text { Faktor A } \\
\text { (g/g) }\end{array}$ & $\begin{array}{c}\text { Faktor B } \\
(\mathrm{mL} / \mathrm{g})\end{array}$ & $\begin{array}{c}\text { Faktor C } \\
\text { (menit) }\end{array}$ & $\begin{array}{c}\text { Faktor D } \\
(\% \\
\text { Watt) }\end{array}$ & $\begin{array}{c}\text { Respon } \\
\text { Aktual (mg } \\
\text { GAE/g } \\
\text { sampel) }\end{array}$ & $\begin{array}{c}\text { Respon } \\
\text { Prediksi } \\
\text { (mg GAE/g } \\
\text { sampel) }\end{array}$ \\
\hline 24 & 1 & 5 & 20 & 15 & 50 & 217,439 & 219,44 \\
\hline 29 & 2 & 5 & 15 & 15 & 30 & 174,315 & 207,38 \\
\hline 7 & 3 & 5 & 15 & 10 & 50 & 167,493 & 173,66 \\
\hline 5 & 4 & 5 & 15 & 10 & 10 & 195,552 & 227,31 \\
\hline 9 & 5 & 4 & 15 & 15 & 10 & 139,564 & 146,62 \\
\hline 8 & 6 & 5 & 15 & 20 & 50 & 140,058 & 156,02 \\
\hline 27 & 7 & 5 & 15 & 15 & 30 & 198,034 & 207,38 \\
\hline 26 & 8 & 5 & 15 & 15 & 30 & 191,940 & 207,38 \\
\hline 3 & 9 & 4 & 20 & 15 & 30 & 203,564 & 219,19 \\
\hline 2 & 10 & 6 & 10 & 15 & 30 & 180,408 & 210,14 \\
\hline 6 & 11 & 5 & 15 & 20 & 10 & 219,312 & 209,68 \\
\hline 10 & 12 & 6 & 15 & 15 & 10 & 119,397 & 133,40 \\
\hline 20 & 13 & 6 & 15 & 20 & 30 & 208,050 & 214,07 \\
\hline 12 & 14 & 6 & 15 & 15 & 50 & 179,900 & 200,85 \\
\hline 11 & 15 & 4 & 15 & 15 & 50 & 213,965 & 214,07 \\
\hline 16 & 16 & 5 & 20 & 20 & 30 & 320,344 & 313,84 \\
\hline 4 & 17 & 6 & 20 & 15 & 30 & 239,980 & 248,66 \\
\hline 18 & 18 & 6 & 15 & 10 & 30 & 256,260 & 227,52 \\
\hline 28 & 19 & 5 & 15 & 15 & 30 & 320,800 & 207,38 \\
\hline 15 & 20 & 5 & 10 & 20 & 30 & 313,685 & 318,02 \\
\hline 25 & 21 & 5 & 15 & 15 & 30 & 198,294 & 194,05 \\
\hline 23 & 22 & 5 & 10 & 15 & 50 & 268,813 & 207,38 \\
\hline 13 & 23 & 5 & 10 & 10 & 30 & 211,839 & 223,62 \\
\hline 1 & 24 & 4 & 10 & 15 & 30 & 229,383 & 194,05 \\
\hline 14 & 25 & 5 & 20 & 10 & 30 & 174,250 & 266,06 \\
\hline 17 & 26 & 4 & 15 & 10 & 30 & 247,754 & 240,74 \\
\hline 21 & 27 & 5 & 10 & 15 & 10 & 193,052 & 185,28 \\
\hline 19 & 28 & 4 & 15 & 20 & 30 & 229,103 & 223,11 \\
\hline 22 & 29 & 5 & 20 & 15 & 10 & 216,516 & 181,10 \\
\hline
\end{tabular}

Data tersebut diatas (pada Tabel 2) kemudian dianalisis menggunakan program DE12 dengan regresi mutivariat kuadratik model. Koefisien korelasi $\left(\mathrm{R}^{2}\right)$ yang diperoleh dari model perhitungan sebesar 0,7572 yang mengimplikasikan bahwa diatas $75,72 \%$ dapat dijelaskan dengan model ini, kemudian berdasarkan nilai $\mathrm{F}$ hitung dari lack of fit sebesar 0,091 menyiratkan bahwa lack of fit tidak relatif signifikan terhadap kesalahan murni. Nilai signikansi dari nilai $\mathrm{F}$ dari nilai lack of fit sebesar 0,9983 ( $>>0,05)$ tidak signifikan atau sekitar diatas 99,83\% terjadi karena faktor respon permukaan yang digunakan. Nilai $\mathrm{F}$ model sebesar 2,70 yang mengindikasikan bahwa model yang dihasilkan signifikan dan hanya $0,3 \%$ untuk nilai $\mathrm{F}$ model terjadi karena gangguan. Hasil analisis diatas menjelaskan bahwa model dapat diterima. Nilai Prob>F lebih kecil dari 0,05 yang juga mengindikasikan bahwa model signifikan (Tabel 3). Sedangkan korelasi antara hasil kadar polifenol eksperimen (aktual) terhadap kadar polifenol total prediski (hasil perhitungan) menggunakan RSM dengan perangkat lunak DE12 dan BBD seperti yang terlihat pada Gambar 1. Persamaan model regresi diperoleh berupa persamaan yaitu: $21,35 \mathrm{AB}-18,71 \mathrm{BD}-32,05 \mathrm{~A}^{2}+34,78 \mathrm{~B}^{2}-$ $2,50 C^{2}-27,50 D^{2}+60,55 A^{2} D+70,80 B^{2} C+$ $46 \mathrm{~B}^{2} \mathrm{D}+5316 \mathrm{~A}^{2} \mathrm{C}^{2}$

Dimana A adalah konsentrasi NADES (g/g), B adalah ratio solid-liquid $(\mathrm{g} / \mathrm{mL})$ $\mathrm{C}$ adalah waktu ekstrasi (menit), dan D adalah kekuatan mikrowave (\%W). 
Islamudin Ahmad, Wisnu Cahyo Prabowo, Yuspian Nur, Mirhansyah Ardana, Bakti Puji Rahayu, Herman

Optimasi Metode Ekstraksi Berbantu Mikrowave dengan Pelarut Hijau (Asam Sitrat-Glukosa) Terhadap Kadar Polifenol Total dari Daun Kadamba (Mitragyna speciosa Korth. Havil) Menggunakan Response Surface Methodology

\begin{tabular}{|c|c|c|c|c|c|}
\hline Source & $\begin{array}{l}\text { Sum of } \\
\text { Squares }\end{array}$ & $d f$ & $\begin{array}{l}\text { Mean } \\
\text { square }\end{array}$ & $\begin{array}{c}F- \\
\text { value }\end{array}$ & $\begin{array}{c}p- \\
\text { value }\end{array}$ \\
\hline Model & 45314,84 & 11 & 4119,53 & 2,93 & 0,0228 \\
\hline A-Rasio NADES & 524,55 & 1 & 524,55 & 0,3733 & 0,5493 \\
\hline $\begin{array}{l}\text { B-Rasio Cair- } \\
\text { Padat }\end{array}$ & 52,45 & 1 & 52,45 & 0,0373 & 0,8491 \\
\hline $\begin{array}{l}\text { C-Waktu } \\
\text { Ekstraksi }\end{array}$ & 621,92 & 1 & 621,92 & 0,4426 & 0,5148 \\
\hline $\begin{array}{l}\text { D-Kekuatan } \\
\text { Mikrowave }\end{array}$ & 2879,02 & 1 & 2879,02 & 2,05 & 0,1705 \\
\hline$A B$ & 1822,91 & 1 & 1822,91 & 1,30 & 0,2705 \\
\hline $\mathrm{B}^{2}$ & 5513,30 & 1 & 5513,30 & 3,92 & 0,0640 \\
\hline $\mathrm{C}^{2}$ & 2162,97 & 1 & 2162,97 & 1,54 & 0,2316 \\
\hline$D^{2}$ & 7616,88 & 1 & 7616,88 & 5,42 & 0,0325 \\
\hline$A^{2} D$ & 7333,66 & 1 & 7333,66 & 5,22 & 0,0355 \\
\hline $\mathrm{B}^{2} \mathrm{C}$ & 13367,80 & 1 & 13367,80 & 9,51 & 0,0067 \\
\hline$B^{2} D$ & 4231,86 & 1 & 4231,86 & 3,01 & 0,1008 \\
\hline Residual & 23889,61 & 17 & 1405,27 & & \\
\hline Lack of Fit & 9956,05 & 13 & 765,85 & 0,219 & 0,9838 \\
\hline Pure Error & 13933,55 & 4 & 3483,39 & & \\
\hline Cor Total & 69204,45 & 28 & & & \\
\hline
\end{tabular}

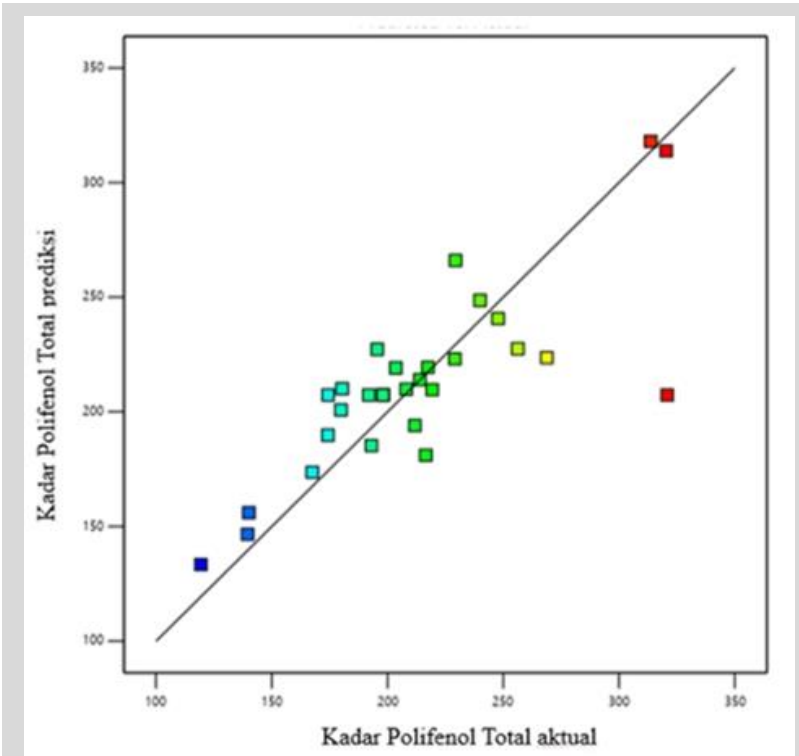

Gambar 1. Plot korelasi antara hasil penetapan kadar polifenol total aktual (ekperimen) dan hasil kadar polifenol total prediksi (hasil perhitungan) menggunakan software Design Expert versi 12 dengan metode respon permukaan dan box behnken design (BBD)
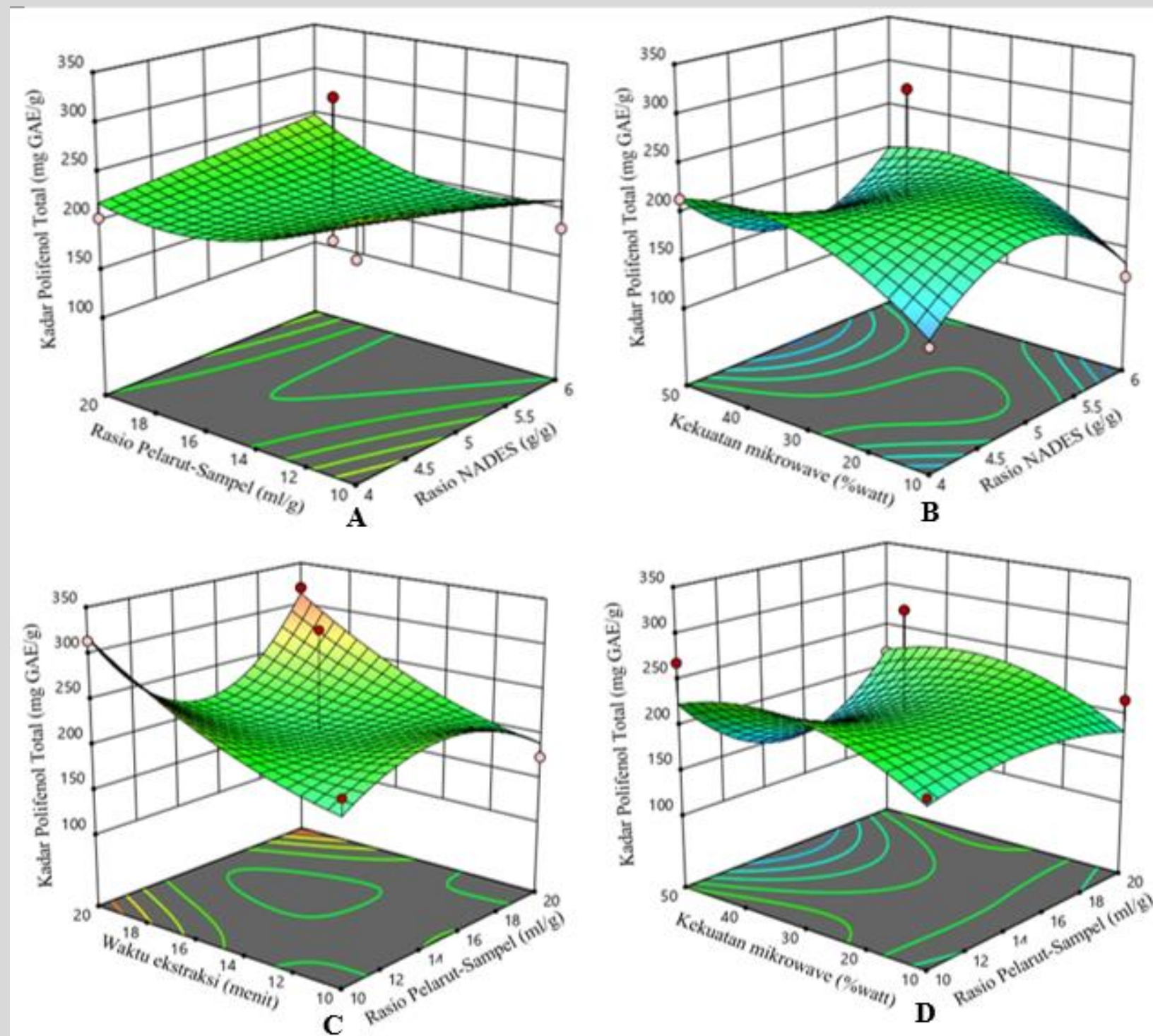

Gambar 1. Plot respon permukaan secara 3 Dimensi memperihatkan pengaruh dari: (A) Rasio NADES dan Rasio Pelarut-Sampel, (B) Rasio NADES dan Kekatan mukrowave, (C) waktu ekstraksi dan rasio pelarut-sampel, dan (D) Kekuatan mikrowave dan rasio pelarut-sampel terhadap nilai respon (kadar polifenol total) 
Kemudian model yang diperoleh dapat dilihat dalam bentuk grafik respon permukaan tiga dimensi (3D) yang dapat dilihat pada Gambar 2. Bentuk grafik yang sesuai untuk menggambarkan kondisi optimum dari model ini yaitu menyerupai parabola, dengan titik optimum berada ditengah. kondisi optimum seharusnya ditunjukan dengan adanya warna merah pada lengkungan yang diikuti dengan warna hijau dan biru yang menandakan adanya penurunan. Bentuk grafik 3D yang diperoleh dari hasil penetapan kadar polifenol total diatas menunjukkan respon yang belum optimum. Hal ini dilihat berdasarkan warna yang dihasilkan pada model grafik 3D diatas. Respon yang belum optimum dapat disebabkan karena adanya faktor lain yang mempengaruhi meskipun faktor yang digunakan tetap. Namun, meskipun demikian model persamaan yang diperoleh dapat digunakan untuk mengekstraksi kadar polifenol total dari daun Kadamba secara maksimal dengan tetap mempertimbangkan efisiensi jumlah pelarut, waktu ekstraksi, toksisitas, dan dampak lingkungan.

Scale-up confirmation merupakan verifikasi kondisi optimal yang diperoleh terhadap ekstraksi senyawa polifenol total menggunakan metode ekstraksi berbantu mikrowave dengan pelarut hijau asam sitrat dan glukosa. Dari hasil analisis yang diperoleh, parameter yang direkomendasikan yaitu pada perbandingan rasio pelarut NADES (asam sitrat : glukosa) $5: 1 \mathrm{~g} / \mathrm{g}$, rasio pelarut-sampel sebesar $1: 20 \mathrm{~g} / \mathrm{mL}$, waktu ekstraksi selama 20 menit dan kekuatan gelombang mikro sebesar 30\% dengan kadar polifenol total prediksi sebesar 314,924 $\pm 35,95 \mathrm{mg} \mathrm{GAE} / \mathrm{g}$ sampel, sedangkan dari hasil proses verifikasi (scale-up confirmation) yaitu dengan meningkatkan jumlah sampel yang digunakan sebanyak sepuluh kali lipat dengan kadar polifenol total diperoleh sebesar 427,12 $\pm 35,95 \mathrm{mg}$ GAE/g. Sedangkan jika dibandingkan dengan metode konvensional (maserasi), hasil yang diperoleh dengan kondisi ekstraksi optimum jauh lebih tinggi besar dibandingkan dengan metode konvensional.

\section{KESIMPULAN}

Dari hasil penelitian ini, dapat disimpulkan bahwa penggunaan pelarut hijau dalam bentuk NADES dengan komposisi asam sitrat-glukosa yang dikombinasikan dengan metode ekstraksi nonkonvensional berbantu mikrowave sangat efektif dan efisien untuk mengekstraksi polifenol total dari daun kadamba. Dari hasil analisis menggunakan RSM diperoleh kondisi optimum dengan rasio NADES (asam sitrat: glukosa) sebesar 5:1 g/g, rasio pelarut-sampel sebesar 1:20 g/mL, waktu ekstraksi selama 20 menit dan kekuatan gelombang mikro sebesar 30\% dengan kadar polifenol total sebesar 427,12 $\pm 35,95 \mathrm{mg} \mathrm{GAE} / \mathrm{g}$ hasil.

Penelitian ini merupakan langkah awal dalam pengembangan metode ekstraksi untuk memperoleh senyawa target secara cepat, mudah, efisien, dan ramah lingkungan. Hasil penelitian ini diharapkan pula dapat memberikan kontribusi pada pengembangan dan pemanfaatan bahan alam terutama tumbuhan sebagai bahan baku obat herbal dengan pendekatan dan penerapan prinsip kimia hijau (green chemistry).

\section{UCAPAN TERIMA KASIH}

Ucapan terima kasih kami sampaikan kepada Kementerian Riset, Teknologi, dan Perguruan Tinggi (KEMRISTEKDIKTI) Republik Indonesia dan Lembaga Penelitian dan Pengabdian kepada Masyarakat (LP2M) Universitas Mulawarman. Penelitian ini di biayai oleh KEMRISTEKDIKTI melalui Hibah Penelitian Dasar Unggulan Perguruan Tinggi (PDUPT) Tahun 2019-2020 (Nomor Kontrak: 203/UN17.41/KL/2019)

\section{DAFTAR PUSTAKA}

1. Hassan Z, Muzaimi M, Navaratnam V, Yusoff NHM, Suhaimi FW, Vadivelu R, Vicknasingam BK, Amato D, von Horsten S, Ismail NIW, Jayabalan N, Hazim AI, Mansor SM, Muller CP. From Kratom to mitragynine and its derivatives: Physiological and behavioural effects related to use, abuse, and addiction. Neuroscience and Biobehavioral Revies. 2013;37(2):13851.

2. Raini M. Kratom (Mitragyna speciosa Korth): Manfaat, Efek Samping dan Legalitas. Media Litbangkes. 2017;27(3):175-84.

3. Singh D, Narayanan S, Vicknasingam B. Traditional and non-traditional uses of Mitragynine (Kratom): A survey of the literature. Brain Research Bulletin, 2016;126:41-6.

4. Ikhwan D, Harlia, Widiyantoro A. Karakterisasi senyawa sitotoksik dari fraksi etil asetat daun Kratom (Mitragyna speciosa Korth.) dan aktivitasnya terhadap sel kanker payudara T47D. Jurnal Kimia Khatulistiwa. 2018;7(2):18-24.

5. Gomez FJV, Espino M. A greener approach to prepare natural deep eutectic solvents. Analytical Chemistry. 2018;3:6122-5.

6. Ahmad I, Pertiwi AS, Kembaren YH, Rahman A, Mun'in A. Application of natural deep eutectic solvent-based ultrasonic assisted extraction of total polyphenolic and caffeine content from Coffe Beans (Coffea Beans L .) for instant food products. Journal of Applied Pharmaceutical Sciences. 2018;8(8):138-43

7. Dordevic BS, Todorovic ZB, Troter DZ, Stanojevic LP. The extraction of quercetin from waste onion (Allium cepa L) tunic by the aquous solutions of different deep eutectic solvents. Advanced Technologies. 2018;7(2):510.

8. Alishlah T, Mun'in A, Jufri M. Optimization of urea-glycerin based NADESUAE for oxyresveratrol extraction from Morus alba roots for preparation of skin whitening lotion. Journal of Young Pharmacist. 2019;11(2):155-60.

9. Mulia K, Yoksandi Y, Kurniawan N, Pane IF, Krisanti EA. 1,2-Propanediolbetaine as green solvent for extracting $\alpha$-mangostin from the rind of mangosteen fruit: Solvent recovery and physical characteristics. Journal of Physic: Conferences Series. 2019;1198(6).

10. Ahmad I, Yanuar A, Mulia K, Mun'im A. Ionic liquid-based microwaveassisted extraction: Fast and green extraction method of secondary metabolites on medicinal plant. Pharmacognosy Reviews. 2018;12(23):20-6.

11. Dika F, Riswanto O, Rohman A, Pramono S, Martono S. Application of response surface methodology as mathematical and statistical tools in natural product research. Journal of Applied Pharmaceutical Sciences. 2019;9(10):125-33.

12. Dai $Y$, Row KH. Application of natural deep eutectic solvents in the extraction of quercetin from vegetables. Molecules. 2019;24(12).

13. Dai Y, Jin R, Verpoorte R, Lam W, Cheng YC, Xiao Y, Xu J, Zhang L, Qin XM, Chen S. Natural deep eutectic characteristics of honey improve the bioactivity and safety of traditional medicines. Journal of Ethnopharmacology. 2020;250(December 2019):112460.

14. Dai Y, Rozema E, Verpoorte R, Choi YH. Application of natural deep eutectic solvents to the extraction of anthocyanins from Catharanthus roseus with high extractability and stability replacing conventional organic solvents. Journal of Chromatography A. 2016;1434:50-56.

15. Dai Y, Witkamp GJ, Verpoorte R, Choi YH. Tailoring properties of natural deep eutectic solvents with water to facilitate their applications. Food Chemistry. 2015;187:14-19.

16. Savi L, Dias M, Carpine D, Waszcynskyj N, Ribani R, Haminiuk C. Natural deep eutectic solvents (NADES) based on citric acid and sucrose as a potential green technology : a comprehensive study of water inclusion and its effect on thermal, physical and rheological properties. International Journal of Food Science Technology. 2018;54(3):898-907.

17. Ahmad I, Yanuar A, Mulia K, Mun A. Optimization of ionic liquid-based micowave-assisted extraction of polyphenolic content from Peperomia pellucida (L) Kunth using response surface methodology. Asian Pacific Journal of Tropical Biomedicine. 2017;7(7):660-665.

18. Chanioti S, Tzia C. Extraction of phenolic compounds from olive pomace by using natural deep eutectic solvents and innovative extraction techniques. Innovative Food Science and Emerging Technology. 2018;48:228-239.

19. Wang H, Ma X, Cheng Q, Xi X, Zhang L. Deep eutectic solvent-based microwave-assisted extraction of baicalin from Scutellaria baicalensis Georgi. Journal of Chemistry. 2018;2018:1-10.

20. Xie Y, Liu H, Lin L, Zhao M, Zhang L, Zhang Y, Wu Y. Application of natural deep eutectic solvents to extract ferulic acid from Ligusticum chuanxiong Hort with microwave assistance. RSC Advances. 2019;9(39):22677-84.

21. Margraf T, Karnopp AR, Rosso ND, Granato D. Comparison between FolinCiocalteu and Prussian Blue assays to estimate the total phenolic content of Juices and teas using 96-Well microplates. Journal of Food Science. 2015;80(11):2397-403.

22. Ainsworth EA, Gillespie KM. Estimation of total phenolic content and other oxidation substrates in plant tissues using Folin - Ciocalteu reagent. Natural Protocol. 2007;2(4):875-7.

23. Sanchez-Rangel JC, Benavides J, Heredia JB, Cisneros-Zevallos L, JacoboVelasquez DA. The Folin-Ciocalteu assay revisited: improvement of its specificity for total phenolic content determination Juan. Analytical Methods. 2013;(21):1-10.

24. Bobo-García G, Davidov-Pardo G, Arroqui C, Marín-Arroyo MR, Navarro M. Intra-laboratory validation of microplate methods for total phenolic content and antioxidant activity on polyphenolic extracts, and comparison with conventional spectrophotometric methods. Journal of Science Food and Agriculture. 2014;95(1):204-9. 
25. Filip S, Pavli B, Vidovi S, Vladi J, Zekovi Z Optimization of microwaveassisted extraction of polyphenolic compounds from Ocimum basilicum by response surface methodology. Food Anaytical Methods. 2017;2017:1-11

26. Lu W, Alam MA, Pan Y, Wu J, Wang Z, Yuan Z. A new approach of microalgal biomass pretreatment using deep eutectic solvents for enhanced lipid recovery for biodiesel production. Bioresource Technology. 2016;218:123-128.

27. Yang L, Li L, Hu H, Wan J, Li P. Natural deep eutectic solvents for simultaneous extraction of multi-bioactive components from jinqi jiangtang preparations. Pharmaceutics. 2019;11(1).

28. Henningfield JE, Fant R V, Wang DW. The abuse potential of kratom according the 8 factors of the controlled substances act: implications for regulation and research. Pshychopharmacology. 2018;235:573-89.

29. Apryani E, Hidayat MT, Moklas MAA, Fakurazi S, Idayu NF. Effects of mitragynine from Mitragyna speciosa Korth leaves on working memory. Journal of Ethnopharmacology. 2010;129(3):357-60.

30. Luliana S, Robiyanto, Islamy MR. Aktivitas Antinosiseptif Fraksi Diklorometana Daun Kratom (Mitragyna speciosa Korth.) rute oral pada mencit jantan Swiss. Pharmaceutical Science and Research. 2018;5(2):58-64.

31. Parthasarathy S, Azizi I Bin, Ramanathan S, Ismail S, Sasidharan S, Mohd MI, et al. Evaluation of antioxidant and antibacterial activities of aqueous, methanolic and alkaloid extracts from Mitragyna speciosa (rubiaceae family) leaves. Molecules. 2009;14(10):3964-74.

32. Mukhriani. Ekstraksi, Pemisahan Senyawa, dan Identifikasi Senyawa Aktif. Kesehatan. 2014;VII NO. 2:7.

33. Yin-Leng K, Suyin G. Natural deep eutectic solvent (NADES) as a greener alternative for the extraction of hydrophilic (polar) and lipophilic (nonpolar) phytonutrients. Key Engineering and Materials. 2019;797:20-8.

34. Mišan A, Nađpal J, Stupar A, Pojić M, Mandić A, Verpoorte R, Choi YH. The perspectives of natural deep eutectic solvents in agri-food sector. Critical Reviews in Food Science and Nutrition. 2019; 1-29. Available from: https://doi.org/10.1080/10408398.2019.1650717

35. Liu Y, Friesen JB, McAlpine JB, Lankin DC, Chen SN, Pauli GF. Natural deep eutectic solvents: Properties, Applications, and Perspectives. Journal of Natural Products. 2018;81(3):679-90.

36. van Osch DJGP, Dietz CHJT, Van Spronsen J, Kroon MC, Gallucci F, van Sint Annaland M, Tuinier R. A search for natural hydrophobic deep eutectic solvents based on natural components. ACS Sustainable Chemistry and Engineering. 2019;7(3):2933-42.

37. Vanda H, Dai Y, Wilson EG, Verpoorte R, Choi YH. Green solvents from ionic liquids and deep eutectic solvents to natural deep eutectic solvents. Comptes Rendus Chimie. 2018;21(6):628-638. 